\title{
Employee diversity attributes of productivity and real remuneration spillover impacts of employee migration to smaller firms in the South African workplace
}

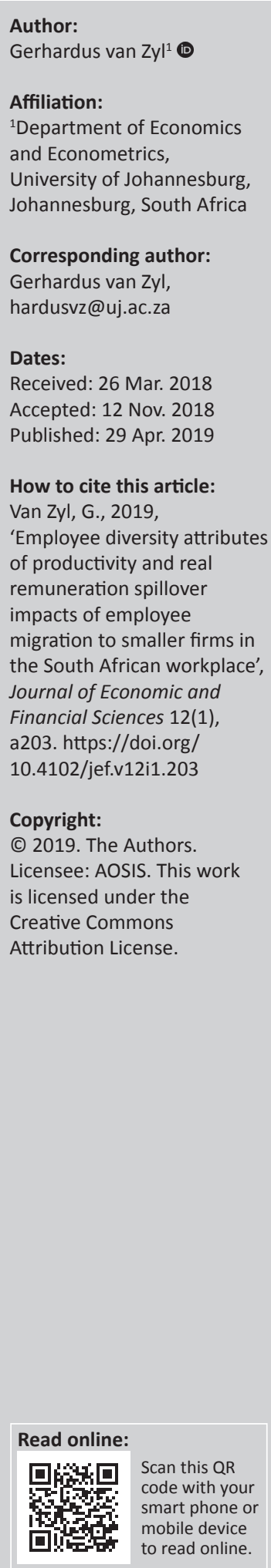

Orientation: This study is part of an ongoing research project on various dimensions of labour productivity in the South African workplace.

Research purpose: The aim of this article was to determine the magnitude of employee migration to smaller firms in the South African workplace and the directional impact of this migration on employee productivity and real remuneration levels when different employee diversity attributes are considered.

Motivation for the study: The study focussed on understanding why the migration of employees from bigger and more labour productive firms can have a positive employee productivity spillover effect on smaller firms.

Research design, approach and method: Two sets of inbound employee migration possibilities were considered, namely employee migration from bigger firms and that from other smaller firms. The manufacturing industry of Gauteng Province of South Africa was used as a case study. Fixed-effect panel data estimations were performed to determine the diversity-based employee productivity and real remuneration effects created by inbound employee migration from bigger firms, other smaller firms and new non-migrating employees.

Main findings: The estimation results confirm superior positive employee productivity and real remuneration spillover effects because of inbound employee migration from bigger firms. The study also indicates that the positive employee productivity and real remuneration spillover effects because of inbound employee migration are greater for a more employeediverse workplace.

Practical/managerial implications: Skills training and the retention of skilled employees are of utmost importance if employee productivity in firms is to be enhanced.

Contribution/value-add: The study confirms the greater employee productivity and remuneration spillover impacts of employee migration to smaller firms in the South African workplace. The size of the employee productivity and remuneration effects also vary according to employee diversity attributes.

Keywords: inbound employee migration; diversity attributes; fixed-effect panel data estimations; employee productivity; real remuneration; bigger firms.

\section{Introduction}

The aim of this article is to determine the magnitude of employee migration to smaller firms in the South African workplace and the directional impact of this migration on employee productivity and real remuneration levels when different employee diversity attributes are considered. Two sets of inbound employee migration possibilities are considered, namely employee migration from bigger firms and that from other smaller firms. The manufacturing industry of Gauteng Province of South Africa is used as a case study.

This article forms part of an extensive ongoing research agenda on various aspects of firm-based employee productivity in the South African workplace such as industry differences on remuneration gap-enhanced labour productivity levels (Van Zyl 2012), the link between different age-skill categories and employee productivity (Van Zyl 2013), the impact of employee diversity on labour productivity (Van Zyl 2014), the impact of incentive schemes on employee productivity (Van Zyl 2015), non-unionised participation platforms and employee productivity (Van Zyl 2016) and the impact of in-house training and employee productivity (Van Zyl 2017). 
Effective knowledge transfer (because of superior technological know-how, managerial and production efficiencies and economies of scale) between firms via employee migration could act as an important conductor for higher employee productivity levels and real remuneration levels (Castillo et al. 2016; Csafordi et al. 2016; Helpman, Melitz \& Yeaple 2004; Le Mouel 2017; Markussen 2002; Pöschl \& Foster-Mcgregor 2016; Serafinelli 2012; Stoyanov \& Zubanov 2012). Given the dynamics of diversity attributes in the South African workplace, it is of the utmost importance that various employee diversity attributes (such as skill levels, gender, age and race) are considered when the impact of knowledge transfer (via inbound employee migration) on employee productivity and real remuneration is estimated. Literature on the impact of knowledge transfer between firms (via employee migration) on employee productivity, remuneration levels and net profitability for developed economies is substantial and mainly indicates positive impacts on both employee productivity and employee remuneration levels (Balsvik 2006; Castillo et al. 2016; Görg \& Strobl 2005; Ilmakunnas, Maliranta \& Pesola 2014; Pöschl \& Foster-Mcgregor 2016; Stoyanov \& Zubanov 2012; Thulin 2009). Research in this regard for developing economies is limited. To expand the debate on firm-based employee productivity in South Africa, it is deemed important to focus specifically on the employee diversity attributes of the magnitude and the directional impact of employee productivity and real remuneration levels when inbound employee migration occurs.

\section{Literature study}

A number of published researches deal with the impact that multinational firms have on the transfer of higher employee productivity levels to domestic firms (Castillo et al. 2016; Csafordi et al. 2016; Helpman et al. 2004; Ilmakunnas et al. 2014; Le Mouel 2017; Markussen 2002; Pöschl \& FosterMcgregor 2016). The general conclusions of all these studies are that multinational firms are in almost all instances bigger than domestic firms and that employee productivity transfers from bigger multinational firms to smaller domestic firms are superior to possible employee productivity transfers from smaller domestic firms to bigger multinational firms. This is because of the fact that bigger multinational firms have superior technological know-how, managerial efficiencies and brand loyalties. It is argued in the literature that the possibility of enhanced employee productivity spillover effects from bigger multinational firms to smaller domestic firms is because of the fact that the technological skill base of bigger multinational firms is implementable in other markets and that the transfer of higher employee productivity levels from bigger multinational to smaller domestic firms could be because of enhanced employee mobility, technological effects and spillovers generated by backward and forward linkages within a particular industry (Balsvik 2006; Bellak 2004; Blomström \& Kakko 1998; Görg \& Strobl 2005; Helpman et al. 2004; Pöschl \& Foster-Mcgregor 2016; Stoyanov \& Zubanov 2012; Thulin 2009).
In nearly all the studies, positive employee productivity transfer effects are derived, especially for net employee migration from bigger to smaller firms within the same industry and it is strongly argued that the superior technological base of bigger firms is an important channel for the transfer of higher employee productivity levels from bigger to smaller firms (Bellak 2004; Castillo et al. 2016; Serafinelli 2012).

The studies of Fosfuri, Matta and Rönde (2001), Glass and Saggi (2002), Pöschl and Foster-Mcgregor (2016) and Stoyanov and Zubanov (2012) argue for the importance of employee mobility as a prerequisite for any successful employee productivity transfers from bigger to smaller firms. The main argument of these authors is that a higher level of technological know-how transfer from bigger to smaller firms should generate greater levels of employee productivity levels for smaller firms. Researchers are of the opinion that higher levels of access to more advanced technological and managerial efficiencies (provided by bigger firms) and a higher level of employee mobility (especially from bigger to smaller firms) should enable employees in smaller firms to enhance their skill levels and ultimately result in higher employee productivity levels (Balsvik 2006; Gersbach \& Schumtzeler 2003; Görg \& Strobl 2005; Le Mouel 2017; Thulin 2009). This is especially true for employees in managerial positions who migrate from bigger to smaller firms.

None of the studies in the covered literature is firm-based; instead, they employ a national data set that is used in econometric employee decomposition models (Castillo et al. 2016; Diewert \& Fox 2007; Ilmakunnas et al. 2014; Maliranta, Mohner \& Rouvinen 2008). These models specifically measure changes in employee productivity levels for bigger and smaller firms. In more technical terms, the decomposition models result in mathematical equations that measure the level of changes in employee productivity transfers and real remuneration levels. A positive aspect of a national data set and decomposition models is that they provide a more substantial overview of a variety of sectors and the potential employee productivity spillover effects that result from employee migration. The Ilmakunnas et al. (2014) estimations also consider possible profitability effects and the age of employees. This particular study indicates (1) strong positive employee productivity effects and real employee remuneration levels when the direction of employee migration is from bigger to smaller firms, (2) positive employee productivity effects created by employee migration from bigger to smaller firms that is stronger for younger workers and, lastly, (3) a directional employee migration from smaller to bigger firms if the impact on profitability in particular is negative because of a negative employee productivity differential.

The vast majority of the studies deal with the characteristics and magnitude of employee migration from bigger to smaller firms (Balsvik 2006; Castillo et al. 2016; Fosfuri et al. 2001; Gersbach \& Schmutzler 2003; Görg \& Strobl 2005; Maliranta et al. 2008; Møen 2005; Pöschl \& Foster-Mcgregor 2016; Stoyanov \& Zubanov 2012). In these studies, it is argued that 
the employee directional migration from bigger to smaller firms (1) could depend on the superior accumulation of technological know-how and managerial efficiencies within bigger firms, (2) could also be influenced by a situation where younger employees prefer to accumulate valuable knowledge within bigger firms, (3) could also be impacted by the unwillingness of bigger firms to allow the transfer of technological and managerial efficiencies by opting for a higher employee remuneration regime, (4) could also imply that smaller firms that are managed by entrepreneurs who previously worked for bigger firms tend to enhance employee productivity more compared to other smaller firms in the same industry and (5) could also indicate that if the share of employees with bigger firms experience increases in smaller firms, the real percentage positive effect on employee productivity levels exceeds the real percentage increase in employee remuneration levels. The studies of Stoyanov and Zubanov (2012), Møen (2005) and Maliranta et al. (2008) consider the impact of research and development (R\&D) on employee mobility and employee productivity. These studies argue that for firms that are R\&D-intensive, outbound employee migration is limited and the benefits of the resulting higher employee productivity levels accrue to these firms. These studies also argue that if the directional employment migration of $R \& D$-intensive firms to non-intensive $R \& D$ firms does occur, the inbound firms experience substantial net employee productivity and profitability gains.

In conclusion, all the research findings indicate positive spillover effects when inbound employee migration from bigger to smaller firms occurs. A very limited number of these studies consider any specific diversity attributes in the workplace.

\section{Research design \\ Research approach and method}

The research design comprises the

- identification of the various diversity attributes to be included in the inbound employee migration - employee productivity estimation model

- specification of the inbound employee migration employee productivity estimation model and employee migration - employee real remuneration estimation model

- compilation of firm-based data sets of inbound employee migration, employee diversity attributes and real remuneration levels for the proxy smaller firms in the sample

- estimation process

- interpretation of the estimation results.

\section{Model specification}

The focus of this article is on the employee productivity and real remuneration spillover effects of inbound employee migration to smaller firms in the South African workplace. Smaller firms are defined as those firms that have on average fewer than 100 employees (Van Zyl 2017). To determine the direction and magnitude of the employee productivity and real remuneration spillover effects, an adapted simplified version of the Ilmakunnas et al. (2014) model is used. The Ilmakunnas et al. (2014) model does not cater for any employee diversity attributes. The employee diversity attributes that are included in the adapted model are gender, race, skill levels and age. To maintain continuity in the broader research agenda on various aspects of firm-based employee productivity in the South African workplace, the same descriptors used for employee diversity attributes in previous publications are applied (Van Zyl 2017). For the gender attribute, a gender distribution of less than $25 \%$ female participation and a gender distribution of more than $25 \%$ female participation in the workplace are applied; for race, a category in which one specific race group has more than a $60 \%$ share and a category where no particular race group has more than a $60 \%$ share in the workplace are used; for age, three groups are used, namely employees 35 years of age and younger, employees between 35 and 55 years of age and employees 55 years of age and older, and for skill levels, the International Standard Classification of Occupations (ISCO-88) is used in order to distinguish between more skilled occupations (category A) and less skilled occupations (category B) in the workplace. Employee productivity growth is defined as an annual 3-year rate of change in real sales per employee. Real employee remuneration growth is defined as an annual 3-year rate of change in real remuneration per employee. To perform a complete set of estimations on the impact of inbound migrating employees on employee productivity and real remuneration levels, it is deemed necessary to also include the impact of new nonmigrating employees on the employee productivity and real remuneration levels of smaller firms. Three separate estimations are performed.

The first estimation is performed to determine the impact on employee productivity levels of smaller firms when inbound employee migration occurs without taking employee diversity attributes into consideration.

The second estimation is performed to determine the impact on real remuneration levels for smaller firms when inbound employee migration occurs without taking the different employee diversity dimensions into consideration.

The third estimation is performed to determine the impact on employee productivity levels of smaller firms when inbound employee migration occurs and the different employee diversity dimensions are considered.

The fourth estimation is performed to determine the impact on real remuneration levels for smaller firms when inbound employee migration occurs and when the different employee diversity dimensions are considered. The different adapted estimation equations are explained in the following few paragraphs. 
In the first equation, the employee productivity effects of inbound migrating employees (without considering various employee diversity dimensions) are expressed as

$\Delta Y_{i, t, t+3}=\alpha_{Y / L}+\sum_{i, t} \beta_{(Y / L) i, t, t+3, \text { migrate bigger }} M L_{i, t, t+3}+\sum_{i, t} \beta_{(Y / L) i, t, t+3 \text { migrate }}$ $\underset{\text { smaller }}{ } M S_{i, t, t+3}+\sum_{i, t} \beta_{(Y L) i, t, t+3 \text { 3non-migrating new }} M N_{i, t, t+3}+\delta{ }^{\prime} Z+\varepsilon$

where $\Delta Y_{i, t, t+3}$ is the change in real sales for firm $i$ from period $t$ to $t+3 ;-\alpha_{Y / L}$ is the fixed component that is common to average employee productivity levels for all the firms such as an employee productivity growth trend; $\sum_{e j} \beta_{(Y / L) i, t, t+3 \text { migrate bigger }}$ is the sum of the average employee productivity level for migrating employees from bigger to smaller firms for firm $i$ for the period $t$ to $t+3 ; M L_{i, t, t+3}$ is the number of migrating employees from bigger to smaller firms at period $t$ to $t+3$ divided by the total number of employees at period $t$ to $t+3$; $\sum_{i, t} \beta_{(Y / L) i, t, t+3 \text { migrate smaller }}$ is the sum of the average employee productivity levels for migrating employees from other smaller firms for the period $t$ to $t+3 ;-M S_{i, t, t+3}$ is defined as the number of migrating employees from other smaller firms divided by the number of employees in smaller firms at period $t$ to $t+3 ; \sum_{i, t, \beta_{(Y / L) i, t, t+3 n e w}}$ is the sum of the average employee productivity levels for non-migrating new employees employed by smaller firms for the period $t$ to $t+3 ;-M N_{i, t, t+3}$ is the number of non-migrating new employees employed by smaller firms; $\delta^{\prime} Z$ is a control variable that accounts for exogenous impacts on employee productivity such as capital; $\varepsilon$ is the error term that includes firm differences for different groups of employees.

The equation basically measures the difference between the average employee productivity of migrating employees from bigger to smaller firms and existing employees $\left(\beta_{(Y / L) i, t, t+3, \text { migrate bigger }}=\frac{(Y / L) i, t \text { migrate from bigger firms }}{\left(\frac{Y}{L}\right)}\right)$, the difference between average employee productivity for migrating employees from other smaller firms and existing employees $\left(\beta_{(Y / L) i, t, t+3, \text { migrate smaller }}=\frac{(Y / L) i, t \text { migrate from smaller firms }}{\left(\frac{Y}{L}\right)}\right)$ and finally the difference between the average employee productivity of non-migrating new employees and existing employees $\left(\beta_{(Y / L) i, t, t+3, \text { non-migrate smaller }}=\frac{\left(\frac{Y}{L}\right) i, t \text { new non }- \text { migrate }}{\left(\frac{Y}{L}\right)}\right)$.

Equation 2 measures the real remuneration spillover effects of inbound migrating employees (without considering various employee diversity attributes) and is expressed as:

$\Delta E R_{i, t, t+3}=\alpha_{E R / L}+\sum_{i, t} \beta_{(E R / L) i, t, t+3, \text { migrate bigger }} M L_{i, t, t+3}+$

$\sum_{i, t} \beta_{(E R / L) i, t, t+3 \text { migrate smaller }} M S_{i, t, t+3}+$

$\sum_{i, t} \beta_{(E R / L) i, t, t+3 \text { non-migrating new }} M N_{i, t, t+3}+\delta^{\prime} Z+\varepsilon$,

[Eqn 2]

where $\Delta E R_{i, t, t+3}$ is the change in real remuneration for firm $i$ from period $t$ to $t+3 ;-\alpha_{\mathrm{ER} / L}$ is the fixed component that is common to average real remuneration levels for all the firms; $\Sigma_{e j} \beta_{(E R / L) i t, t+3, \text { migrate bigger }}$ is the sum of average real remuneration levels for migrating employees from bigger to smaller firms for firm $i$ for the period $t$ to $t+3 ; M L_{i, t, t+3}$ is the number of migrating employees from bigger to smaller firms at period $t$ to $t+3$ divided by the total number of employees at period $t$ to $t+3$; $\sum_{i, t} \beta_{\text {(ER/Lit,t+3migrate smaller }}$ is the sum of the average real remuneration levels for migrating employees from other smaller firms for the period $t$ to $t+3 ;-M S_{i, t, t+3}$ is defined as the number of migrating employees from other smaller firms divided by the number of employees in smaller firms at period $t$ to $t+3 ; \sum_{i, t} \beta_{(E R / L) i, t, t+3 \text { new }}$ is the sum of the average real remuneration levels for nonmigrating new employees employed by smaller firms for the period $t$ to $t+3 ; M N_{i, t+3}$ is the number of non-migrating new employees employed by smaller firms; $\delta^{\prime} \mathrm{Z}$ is a control variable that accounts for exogenous impacts on employee remuneration such as capital; $\varepsilon$ is the error term that includes firm differences for different groups of employees.

The equation basically measures the difference between the average real remuneration levels of migrating employees from bigger firms and existing employees $\left(\beta_{(E R / L) i, t, t+3, \text { migrate bigger }}=\frac{(E R / L) i, t \text { migrate from bigger firms }}{\left(\frac{E R}{L}\right)}\right)$, the difference between average real remuneration levels for migrating employees from other smaller firms and existing employees $\beta_{(E R / L) i, t, t+3, \text { migrate }}$ smaller $=$ $(E R / L) i, t$ migrate from smaller firms

$$
\left(\frac{E R}{L}\right) \quad \text { and finally the difference }
$$

between the average real remuneration levels of nonmigrating new employees and existing employees

$\left(\beta_{(E R / L) i, t, t+3, \text { non-migrate smaller }}=\frac{\left(\frac{E R}{L}\right) i, t \text { new non }- \text { migrate }}{\left(\frac{E R}{L}\right)}\right)$.

In the third equation, employee productivity spillover effects of inbound migrating employees (when various employee diversity dimensions are considered) are expressed as:

$\Delta Y_{i, t, t+3}=\alpha_{Y / L}+\sum_{i, t} \beta_{(Y / L) j, t, t+3 \text {,migrate bigger }} M L_{i, t, t+3} \varnothing_{i, t, t+3}+$

$\sum_{i, t} \beta_{(Y / L) i, t, t+3 \text { migrate smaller }} M S_{i, t, t+3} \varnothing_{i, t, t+3}+\sum_{i, t} \beta_{(Y / L) i, t, t+3 \text { 3non-migrating new }}$

$M N_{i, t, t+3} \varnothing_{i, t, t+3}+\delta^{\prime} Z+\varepsilon$

[Eqn 3]

where $\Delta Y_{i, t, t+3}$ is the change in real sales for firm $i$ for period $t$ to $t+3 ;-\alpha_{Y / L}$ is the fixed component that is common to average employee productivity levels for all the firms such as an employee productivity growth trend; $\Sigma_{e} \beta_{(Y / L) i, t, t+3 \text {,migrate bigger }}$ is the sum of the average employee productivity level for migrating employees from bigger to smaller firms for firm $i$ for the period $t$ to $t+3 ; M L_{i, t, t+3}$ is the number of migrating employees from bigger to smaller firms at period $t$ to $t+3$ divided by the total number of employees at period $t$ to $t+3$; $\varnothing_{i, t, t+3}$ is the diversity attributes for firm $i$ for period $t$ to $t+3$; 
$\sum_{i, t} \beta_{(Y / L) i, t, t+3 \text { migrate smaller }}$ is the sum of the average employee productivity levels for migrating employees from other smaller firms for the period $t$ to $t+3 ; M S_{i, t, t+3}$ is defined as the number of migrating employees from other smaller firms divided by the number of employees in smaller firms at period $t$ to $t+3 ; \Sigma_{i, t} \beta_{(Y / L) i, t, t+3 \text { new }}$ is the sum of the average employee productivity levels for non-migrating new employees employed by smaller firms for the period $t$ to $t+3$; $M N_{i, t, t+3}$ is the number of non-migrating new employees employed by smaller firms. $\delta^{\prime} Z$ is a control variable that accounts for exogenous impacts on employee productivity such as capital; $\varepsilon$ is the error term that includes firm differences for different groups of employees.

Equation 3 measures the difference between the average employee productivity of migrating employees from bigger firms and existing employees per diversity attribute, the difference between the average employee productivity for migrating employees from other smaller firms and existing employees per diversity attribute and the difference between the average employee productivity of non-migrating new employees and existing employees per diversity attribute.

Equation 4 measures the real remuneration spillover effects of inbound migrating employees (considering various employee diversity attributes) and is expressed as

$\Delta E R_{i, t, t+3}=\alpha_{E R / L}+\sum_{i,,} \beta_{(E R / L) i, t, t+3, \text { migrate bigger }} M L_{i, t, t+3} \varnothing_{i, t, t+3}+$

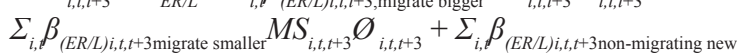

$M N_{i, t, t+3} \varnothing_{i, t, t+3}+\delta^{\prime} Z+\varepsilon$

where $\Delta \mathrm{ER}_{i, t, t+3}$ is the change in real remuneration for firm $i$ for period $t$ to $t+3 ;-\alpha_{E R / L}$ is the fixed component that is common to average real remuneration levels for all the firms; $\Sigma_{e j} \beta_{(E R / L)}$ $i, t, t+3$,migrate bigger is the sum of average real remuneration levels for migrating employees from bigger to smaller firms for firm $i$ for the period $t$ to $t+3 ; M L_{i, t, t+3}$ is the number of migrating employees from bigger to smaller firms at period $t$ to $t+3$ divided by the total number of employees at period $t$ to $t+3$; $\varnothing$ $i, t, t+3$ is the diversity attributes for firm $i$ for period $t$ to $t+3$; $\sum_{i, t} \beta_{(E R / L) i, t,+3 \text { migratesmaller }}$ is the sum of the average real remuneration levels for migrating employees from other smaller firms for the period $t$ to $t+3 ; M S_{i, t, t+3}$ is defined as the number of migrating employees from other smaller firms divided by the number of employees in smaller firms at period $t$ to $t+3$; $\Sigma_{i, t} \beta_{(E R / L) i, t, t+3 \text { new }}$ is the sum of the average real remuneration levels for non-migrating new employees employed by smaller firms for the period $t$ to $t+3 ; M N_{i, t, t+3}$ is the number of nonmigrating new employees employed by smaller firms; $\delta^{\prime} Z$ is a control variable that accounts for exogenous impacts on employee remuneration such as capital; $\boldsymbol{\varepsilon}$ is the error term that includes firm differences for different groups of employees.

The equation basically measures the difference between the average real remuneration levels of migrating employees from bigger firms and existing employees per employee diversity attribute, the difference between the average real remuneration levels for migrating employees from other smaller firms and existing employees per employee diversity attribute and finally the difference between the average real remuneration levels of non-migrating new employees and existing employees per employee diversity attribute.

The study employs fixed-effect panel data estimations for all the inbound employee migration - employee productivity and the inbound employee migration - real remuneration level categories per diversity attribute.

\section{Data collection process}

To capture the employee productivity and real remuneration impacts of inbound employee migration to smaller firms, the manufacturing industry of Gauteng Province is used as a case study, given the importance of the manufacturing industry in the gross geographical product (GGP) of Gauteng Province and also given the availability of firm-based data. Contact information was supplied by the Manufacturing Sector Education and Training Authority (MERSETA) and the Department of Labour. Firm data were supplied by the individual firms in the sample group. Statistical validation requires a representative sub-sector spread of firms in the manufacturing industry of Gauteng Province. The sample response of 83 firms, which covers a variety of sub-sectors in the Gauteng manufacturing industry, is confirmed to be statistically significant.

The sample period was for 2012-2014. For each firm in the sample group, data were collected on the average annual employment levels per gender group, skill level category, age groups and per race group; average annual real remuneration levels per gender group, skill level categories, age groupings and per race group; average annual real sales per employee; average annual employment rates of new migrating employees from bigger firms; the average annual employment rates of new migrating employees from smaller firms; average annual employment rates for new non-migrating employees; and average annual employee turnover.

A summary of the sample statistics is provided in Appendix 1 . For the sample as a whole male representation is on average $18 \%$ more than female representation, the ratio of one specific race group that has a more than $60 \%$ share of total employees compared to a situation where a specific race group has a less than $60 \%$ share of total employees is on average 1.90:1; the majority of employees are in category B occupations (on average $74 \%$ ); the majority of employees are between 35 and 55 years of age (on average $72 \%$ ); the average real remuneration for male employees is on average $17 \%$ more than for female employees; employees from the same race group that has less than a $60 \%$ share of the total employee base earn on average 16\% more than employees from a specific race group representing more than $60 \%$ of the total employee base; the average annual real sales per employee increased from $11 \%$ in 2013 to $12 \%$ in 2014; the average annual inbound employee migration rate from bigger firms is higher than the annual inbound migration rate from other smaller firms (3.68\% vs. $2.40 \%)$; the employment of new nonmigrating employees is relatively small $(0.53 \%)$; and the employee turnover rate is on average $1.55 \%$. 


\section{Estimation results}

The panel data estimates (first and second estimations) for the impact of the inbound migration of employees from bigger and other smaller firms on employee productivity and real remuneration levels (without considering employee diversity attributes) are listed in Table 1.

From Table 1, it can be deduced that inbound migration from both bigger firms and other smaller firms has positive impacts on both employee productivity and real remuneration levels. Larger positive impacts on both employee productivity and real remuneration levels are generated by inbound migrating employees from bigger firms. The employee productivity and real remuneration impacts of new nonmigrating employees are positive but relatively insignificant.

Given the insignificant impact of new non-migrating employees on employee productivity and real remuneration levels in the first and second estimations, only the impacts of employee migration from bigger and other smaller firms in the third and fourth estimations are reported. The results of the third and fourth estimations are listed in Table 2.

TABLE 1: Panel data estimates for the impact of inbound employee migration on employee productivity and real remuneration without taking employee diversity dimensions into consideration.

\begin{tabular}{lcc}
\hline Variable & $\begin{array}{c}\text { Employee } \\
\text { productivity } \\
\text { impact estimates }\end{array}$ & $\begin{array}{c}\text { Employee real } \\
\text { remuneration } \\
\text { impact estimates }\end{array}$ \\
\hline Employee migration from bigger firms & $0.371(0.103)$ & $0.281(0.132)$ \\
Employee migration from other smaller firms & $0.131(0.099)$ & $0.175(0.84)$ \\
New non-migrating employees & $0.009(0.0006)$ & $0.003(0.0007)$ \\
Observations & $\mathbf{8 3}$ & $\mathbf{8 3}$ \\
$\boldsymbol{R}^{\mathbf{2}}$ & $\mathbf{0 . 3 4 1}$ & $\mathbf{0 . 3 1 1}$ \\
\hline
\end{tabular}

Note: The estimates are significant at $5 \%$ confidence level.

TABLE 2: Panel data estimates for the impact of inbound employee migration on employee productivity taking employee diversity dimensions into consideration.

\begin{tabular}{|c|c|c|}
\hline Variable & $\begin{array}{c}\text { Employee } \\
\text { productivity } \\
\text { impact estimates }\end{array}$ & $\begin{array}{l}\text { Employee real } \\
\text { remuneration } \\
\text { impact estimates }\end{array}$ \\
\hline \multicolumn{3}{|l|}{ Employee migration from bigger firms } \\
\hline Female participation $>40 \%$ & $0.314(0.121)$ & $0.273(0.107)$ \\
\hline Female participation $<40 \%$ & $0.231(0.115)$ & $0.265(0.099)$ \\
\hline Age $<35$ years & $0.173(0.098)$ & $0.113(0.083)$ \\
\hline Age between 35 and 55 years & $0.363(0.118)$ & $0.413(0.171)$ \\
\hline Age 55 years and older & $0.253(0.097)$ & $0.311(0.152)$ \\
\hline Specific race group more than a $60 \%$ share & $0.191(0.089)$ & $0.201(0.105)$ \\
\hline Specific race group less than a $60 \%$ share & $0.241(0.105)$ & $0.295(0.114)$ \\
\hline Category A occupations & $0.291(0.101)$ & $0.301(0.127)$ \\
\hline Category B occupations & $0.193(0.089)$ & $0.189(0.084)$ \\
\hline \multicolumn{3}{|l|}{ Employee migration from other smaller firms } \\
\hline Female participation $>40 \%$ & $0.203(0.114)$ & $0.190(0.120)$ \\
\hline Female participation $<40 \%$ & $0.173(0.110)$ & $0.181(0.116)$ \\
\hline Age $<35$ years & $0.121(0.097)$ & $0.091(0.009)$ \\
\hline Age between 35 and 55 years & $0.169(0.098)$ & $0.157(0.102)$ \\
\hline Age 55 years and older & $0.162(0.091)$ & $0.137(0.112)$ \\
\hline Specific race group more than a $60 \%$ share & $0.143(0.093)$ & $0.149(0.119)$ \\
\hline Specific race group less than a $60 \%$ share & $0.154(0.101)$ & $0.156(0.117)$ \\
\hline Category A occupations & $0.211(0.111)$ & $0.129(0.096)$ \\
\hline Category B occupations & $0.174(0.117)$ & $0.164(0.127)$ \\
\hline Observations & 83 & 83 \\
\hline$R^{2}$ & 0.371 & 0.392 \\
\hline
\end{tabular}

Note: The estimates are significant at $5 \%$ confidence level.
The panel data estimates (third and fourth estimations) for the impact of the inbound migration of employees from bigger and other smaller firms on employee productivity and real remuneration levels (considering employee diversity attributes) are listed in Table 2.

The estimates of the third and fourth estimations are positive for employee migrations from both bigger and smaller firms. The estimation results clearly indicate that when employee diversity dimensions are considered, the general superior positive employee productivity and real remuneration spillover effects that inbound employee migration from bigger firms generate are still evident.

In terms of the gender dimension, the results indicate that a more gender-diverse workplace does create higher employee productivity and real remuneration spillover effects when inbound employee migration occurs. This is evident from higher positive estimates for the greater than $40 \%$ female participation bracket and it is true for employee migrations from both bigger and other smaller firms. The higher comparative estimates for the 35-55-year age bracket indicate that the greatest employee productivity and real remuneration positive spillover effects are created when employee inbound migration occurs in this age bracket. This is evident for employee inbound migrations from both bigger and other smaller firms. The fact that greater estimates are reported for the category in which a specific race group has less than a $60 \%$ share of the workforce is indicative of greater employee productivity and real remuneration spillover effects that are because of a more diverse racial composition of the workforce (this is true for employee inbound migration from both bigger firms and other smaller firms). The estimation results indicate that the inbound migration of higher skilled employees results in higher employee productivity and real remuneration levels spillover effects (the estimates for category A occupations are higher than the estimates for occupation B estimates).

What can we learn from the results of this study and how do the results compare with the experience of developed economies in this regard? Firstly, the results of this particular study confirm the importance of inbound employee migration as an important conductor for the transfer of knowledge, higher skill levels, technological know-how and managerial efficiencies to smaller firms (even in a developing economy such as South Africa). Secondly, the results confirm the importance of a more diverse South African workplace if the positive productivity and real remuneration levels generated by inbound employee migration are to be optimised.

\section{Conclusion}

The aim of this article was to determine the magnitude of employee migration to smaller firms in the South African workplace and the directional impact of this migration on employee productivity and real remuneration levels when different employee diversity attributes are considered. 
To determine the employee productivity and real remuneration spillover effects of inbound employee migration to smaller firms in the South African workplace, inbound employee migrations from both bigger and smaller firms were considered. The results of this study are firstly a confirmation of international research results (Balsvik 2006; Görg \& Strobl 2005; Castillo et al. 2016; Csafordi et al. 2016; Ilmakunnas et al. 2014) that indicate the importance of the transfer of knowledge between firms (via employee migration) in the workplace to enhance employee productivity and real remuneration levels. Secondly, the results of the study clearly indicate that employee inbound migration from bigger firms in particular has a greater employee productivity and real remuneration spillover potential for smaller firms in the workplace. Thirdly, the positive spillover effects because of inbound employee migration are more prominent in a more gender-diverse workplace, in a more racially diverse workplace, in a more skilled workforce and in firms that retain more experienced employees.

A further extension of the study is a geographical (provincial) comparison on the magnitude of employee migration to smaller firms in the South African workplace and the directional impact of this migration on employee productivity and real remuneration levels when different employee diversity attributes are considered.

\section{Acknowledgements Competing interests}

The author declares that he has no financial or personal relationships that may have inappropriately influenced him in writing this article.

\section{References}

Balsvik, R., 2006, Is mobility of labor a channel for spill-overs from multinationals to local domestic firms? Discussion paper no. 25/06, Department of Economics, Norwegian School of Economics and Business Administration, Oslo.

Bellak, C., 2004, 'How domestic and foreign firms differ and why does it matter?', Journal of Economic Surveys 18, 483-514. https://doi.org/10.1111/j.0950-0804. 2004.00228.x

Blomström, M. \& Kokko, A., 1998, 'Multinational corporations and spill-overs', Journal of Economic Surveys 12, 247-277. https://doi.org/10.1111/1467-6419.00056 Castillo, V., Figal-Garane, L., Muffioli, A., Rojo, S. \& Stucchi, R., 2016, The effects of
knowledge spillovers through labor mobility, Munich Personal RePEc Archive (MPRS) Paper Series, no. 69141, Munich University Library, Munich.
Csafordi, Z., Lorincz, L., Lengyel, B. \& Kiss, K.M., 2016, The effect of productivity gap, foreign-owned firms, and skill-relatedness, Institute of Economics Centre for Economic and Regional Studies (IECER) Discussion Paper Series, no. 1610, Hungarian Academy of Sciences, Budapest.

Diewert, W.E. \& Fox, K.J., 2007, On measuring the contribution of entering and exiting firms to agregate productivity growth, Index Number Theory and the Measurement of Prices and Productivity, Trafford Publishing, Victoria.

Fosfuri, A., Motta, M. \& Rönde, T., 2001, 'Foreign direct investment and spill-overs through workers mobility', Journal of International Economics 53, 205-222. https://doi.org/10.1016/S0022-1996(00)00069-6

Gersbach, H. \& Schmutzler, A., 2003, 'Endogenous technological spill-overs: Causes and consequences', Journal of Economics and Management Strategy 12, 179-205. https://doi.org/10.1162/105864003766754198

Glass, A.J. \& Saggi, K., 2002, 'Multinational firms and technology transfer', Scandinavian Journal of Economics 104, 495-513. https://doi.org/10.1111/1467-9442.00298

Görg, H. \& Strobl, E., 2005, 'Spill-overs from foreign firms through worker mobility: An empirical investigation', Scandinavian Journal of Economics 107, 693-710. https:// doi.org/10.1111/j.1467-9442.2005.00427.x

Helpman, E., Melitz, M. \& Yeaple, S., 2004, 'Export versus FDI with heterogeneous firms', American Economic Review 94, 300-316. https://doi.org/10.1257/ 000282804322970814

Ilmakunnas, P., Maliranta, M. \& Pesola, H., 2014, Spill-overs from multinational to domestic firms: An empirical analysis of the profitability effects of labor flows, viewed 15 June 2017, from https://perso.uclouvain.be/vincent.vandenberghe/ Workshop2014.

Le Mouel, M., 2017, Managerial knowledge spillovers and firm productivity, viewed 10 January 2018, from https://www.diw.de/documents/dokumentenarchiv/17/diw.

Maliranta, M., Mohnen, P. \& Rouvinen, P., 2008, Is inter-firm labor mobility a channel of knowledge spill-overs? Evidence from a linked employer-employee panel, ETLA Discussion Paper, 1116

Markussen, J.R., 2002, Multinational firms and the theory of trade, MIT Press, Cambridge.

Møen, J., 2005, 'Is mobility of technical personnel a source of R\&D spill-overs?', Journal of Labor Economics 23, 81-114. https://doi.org/10.1086/425434

Pöschl, J. \& Foster-Mcgregor, N., 2016, 'Productivity effects of knowledge transfers through labor mobility', Journal of Productivity Analysis 46(2), 199-233.

Serafinelli, M., 2012, Worker mobility and knowledge diffusion in local labor markets, viewed 15 July 2017, from https://escholarship.org/uc/item/2x6576zr.

Stoyanov, A. \& Zubanov, N., 2012, 'Productivity spillovers across firms through worker mobility', American Economic Journal: Applied Economics 4(2), 168-198. https:// doi.org/10.1257/app.4.2.168

Thulin, P., 2009, Labor mobility, knowledge diffusion and regional growth, CESIS Working paper series in Economics and Institutions of Innovation, 209, Royal Institute of Technology, Stockholm.

Van Zyl, G., 2012, 'Geographical and industry differences on remuneration gapenhanced labour productivity levels in a developing economy: South Africa as a case study', Journal of Economic \& Financial Sciences 5(2), 499-514.

Van Zyl, G., 2013, 'Relative labour productivity contribution of different age-skill categories for a developing economy: The Gauteng province of South Africa as a case study', South African Journal of Human Resource Management 11(1), 1-8. https://doi.org/10.4102/sajhrm.v11i1.472

Van Zyl, G., 2014, 'Labour productivity and employee diversity in the South African workplace', Journal of Economic \& Financial Sciences 7(2), 451-466.

Van Zyl, G., 2015, 'The impact of incentive schemes on employee productivity in the South African workplace', Journal of Economic \& Financial Sciences 8(2), 633-647.

Van Zyl, G., 2016, 'The impact of non-unionised participation platforms on employee productivity in the South African workplace', Journal of Economic \& Financia Sciences 9(1), 93-105. https://doi.org/10.4102/jef.v9i1.31

Van Zyl, G., 2017, 'The impact of in-house training on employee productivity in the South African workplace', Journal of Economic \& Financial Sciences 10(1) 160-175. https://doi.org/10.4102/jef.v10i1.11 


\section{Appendix 1}

TABLE 1-A1: Summary statistics.

\begin{tabular}{|c|c|c|c|}
\hline Variable & 2012 & 2013 & 2014 \\
\hline \multicolumn{4}{|l|}{ Average annual employment } \\
\hline - Female & 35 & 36 & 37 \\
\hline - Male & 51 & 53 & 54 \\
\hline - Specific race group more than a $60 \%$ share & 58 & 57 & 59 \\
\hline - Specific race group less than a $60 \%$ share & 28 & 32 & 32 \\
\hline - Category A occupations & 24 & 23 & 23 \\
\hline - Category B occupations & 62 & 66 & 68 \\
\hline - Employees 35 years and younger & 14 & 13 & 15 \\
\hline - Employees between 35 and 55 years of age & 61 & 66 & 64 \\
\hline - Employees 55 years and older & 11 & 10 & 12 \\
\hline \multicolumn{4}{|l|}{ Average annual employee remuneration } \\
\hline - Female & R78 532 & R82 581 & R88 355 \\
\hline - Male & R91 538 & R96 491 & R99 399 \\
\hline - Specific race group more than a $60 \%$ share & R72 665 & R74 209 & R77 411 \\
\hline - Category A occupations & R99 462 & R103 671 & R117 538 \\
\hline - Category B occupations & R70 461 & R78 277 & R82 674 \\
\hline - Employees 35 years and younger & R68 499 & R72 196 & R76 194 \\
\hline - Employees between 35 and 55 years of age & R79 351 & R85 311 & R88 511 \\
\hline - Employees 55 years and older & R83 197 & R91 743 & R94 386 \\
\hline Average annual real sales per employee & R124 137 & R137988 & R154 433 \\
\hline Average annual employment rates: Migrating employees from bigger firms (\%) & 3.45 & 3.76 & 3.82 \\
\hline Average annual employment rates: Migrating employees from other smaller firms(\%) & 2.36 & 2.44 & 2.41 \\
\hline Average annual employment rates: New non-migrating employees (\%) & 0.48 & 0.55 & 0.56 \\
\hline Average annual employee turnover rate $(\%)$ & 1.31 & 1.56 & 1.77 \\
\hline
\end{tabular}

